\title{
A Heuristic Approach to Estimating Spatial Variability of Vertical Leakage in the Recharge Zone of the Gambier Basin Tertiary Confined Sand Aquifer, South Australia
}

\author{
Nara Somaratne ${ }^{1}$, Jeff Lawson' ${ }^{2}$, Saad Mustafa ${ }^{2}$ \\ ${ }^{1}$ South Australian Water Corporation, Adelaide, South Australia \\ ${ }^{2}$ Department of Environment, Water and Natural Resources, Mount Gambier, South Australia \\ Email: "nara.somaratne@sawater.com.au
}

Received 14 January 2016; accepted 14 February 2016; published 17 February 2016

Copyright (C) 2016 by authors and Scientific Research Publishing Inc.

This work is licensed under the Creative Commons Attribution International License (CC BY). http://creativecommons.org/licenses/by/4.0/

\section{(c) (i) Open Access}

\section{Abstract}

The vertical leakage to confined aquifers is rarely quantified in complex settings, where the recharge zone is characterized by both diffuse and preferential flows. In such setting, conventional hydraulic or tracer based estimation of recharge or vertical leakage is problematic, unless the effects of duality of flow regimes are considered. A water balance approach by the use of calibrated groundwater models can be used, as the mass balance is independent of the particular mode of recharge and vertical leakage processes. Here, we adopt a water balance approach to provide a first order assessment of recharge to the unconfined Tertiary limestone aquifer (TLA) and vertical leakage to the Tertiary confined sand aquifer (TCSA) within the Glencoe-Nangwarry-Nagwarry (GNN) recharge zone of the Gambier Basin in South Australia. Despite many studies expressing concern about the impact of land use on recharge to the TLA and vertical leakage to the TCSA, no estimates have been made to quantify the vertical leakage within the GNN recharge zone. In the GNN recharge zone, relatively high recharge to the unconfined aquifer and vertical leakage to the confined aquifer occurs as a result of both diffuse and preferential flow processes. This is due to presence of structural faults and thin or absent aquitard. Within the Hundred of Nangwarry, where $83 \%$ of the area is covered with plantation forest, the model calculated recharge to the TLA of $80 \mathrm{~mm} \cdot \mathrm{year}^{-1}$, about $44 \%$ reduction compared to adjacent non-forested area $\left(144 \mathrm{~mm} \cdot \mathrm{year}^{-1}\right)$. Vertical leakage to the TCSA within the Hundred of Nangwarry area is higher $\left(84.5 \mathrm{~mm} \cdot \mathrm{year}^{-1}\right)$ than recharge to the TLA. Higher vertical leakage combined with the reduced recharge to TLA

\footnotetext{
"Corresponding author.
} 
resulted in depletion of the TLA storage, as evidenced by drying of the TLA at one locality. In contrast, in plantation forest areas where diffuse recharge is the dominant process (Hundred of Pe-

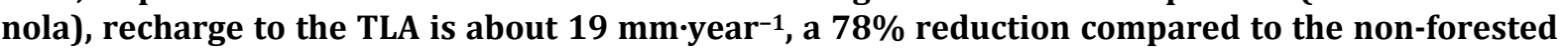
areas, a mix of irrigation and dryland pasture. In these areas, vertical leakage to the TCSA is much smaller: $8 \mathrm{~mm} \cdot \mathrm{mear}^{-1}$ through a thick aquitard. Simulation of a management scenario in which plantation forest is replaced by dryland pasture in the Hundred of Nangwarry results in 135

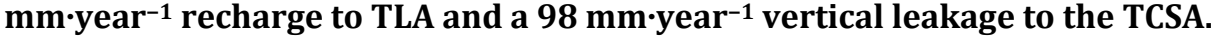

\section{Keywords}

Gambier Basin, Confined Aquifer, Preferential Flows, Vertical Leakage, Groundwater Models, Groundwater Management

\section{Introduction}

Management of regional groundwater systems requires an understanding of the balance between recharge, interaquifer leakage and lateral movement of groundwater. There are currently few reliable hydraulic or tracer based methods for estimating rates of diffuse inter-aquifer leakage through an aquitard. The tracer-based approaches involve one or more of the following: environmental or injected tracer techniques [1]; advection-diffusion modelling of pore water chloride profiles [2]-[4], adoption of the compartmental mixing model approach [5]. Hydraulic based approach to the assessment of site specific vertical leakage from Darcy's equation involve: vertically averaged conductance [6]; based on vertical hydraulic gradient and Darcy flow equation [7]; equivalent hydraulic conductivity approach [8]; adaptation of radial flow theory from pumping test data [9]; analytical solution to pressure perturbation and fluid leakage through the aquitard [10]. Hydraulic-based quantification of vertical leakage can be difficult since the key parameter, vertical hydraulic conductivity can vary considerably. Similarly, tracer or hydraulic based site specific recharge or vertical leakage estimation becomes problematic unless duality of flow regimes (diffuse and preferential) is considered [11] [12].

In the Glencoe-Nangwarry-Nagwarry (GNN) recharge zone (Figure 1) of the Gambier Basin, South Australia, Brown et al. [13] used environmental isotope techniques to study the dynamic behavior of the groundwater systems and concluded that vertical leakage to the confined aquifer is attributed to preferential flows (fractures, faults or sinkholes) rather than via porous media flow through the aquitard. Recently, Somaratne et al. [14] extended the study by Brown et al. [13] to an additional 6 sites and have shown that vertical leakage to the confined aquifer in the GNN recharge zone is characterized by both diffuse and preferential flow processes.

Transient numerical groundwater models are widely used to provide a regional or sub-regional estimate of vertical leakage through aquitards [15] by inverse calibration to heads and groundwater flow rates [16] as models are independent of the mode of recharge and leakage processes. Several groundwater models have been developed for the entire Gambier Basin [17] [18] or outside the GNN recharge zone [19]. These models are at their conceptual stages and may require further work to be used as tools for regional or local water balance calculations.

Groundwater models are valuable tools for analyzing groundwater systems. Nevertheless, applying groundwater models to field problems can result in errors from conceptual deficiencies, numerical errors, and inadequate parameter estimation. As such, models cannot be validated [20] and viewed as the application of distributed hydrological models is more an exercise in prophecy than prediction [21]. Thus, the primary value of models is heuristic [22]. In general, manual procedures for groundwater model calibration can be extremely time-consuming and frustrating [23], and inverse modelling is a key step in groundwater related studies [24]. Boyle et al. [25] however, suggests using the combined strengths of the manual calibration approach, which has been developed and refined over the years; and automatic calibration. The study of Saiers and Bolster [26] shows that even relatively simple models can predict transient groundwater flow in a complex aquifer with reasonable accuracy. Model calibration allows reduced parameter uncertainty and, therefore uncertainty in simulation results [27]. According to Moore and Doherty [28], no matter which regularization methodology is employed for model calibration, the inevitable consequence of its use is a loss of detail in the calibrated field leading 


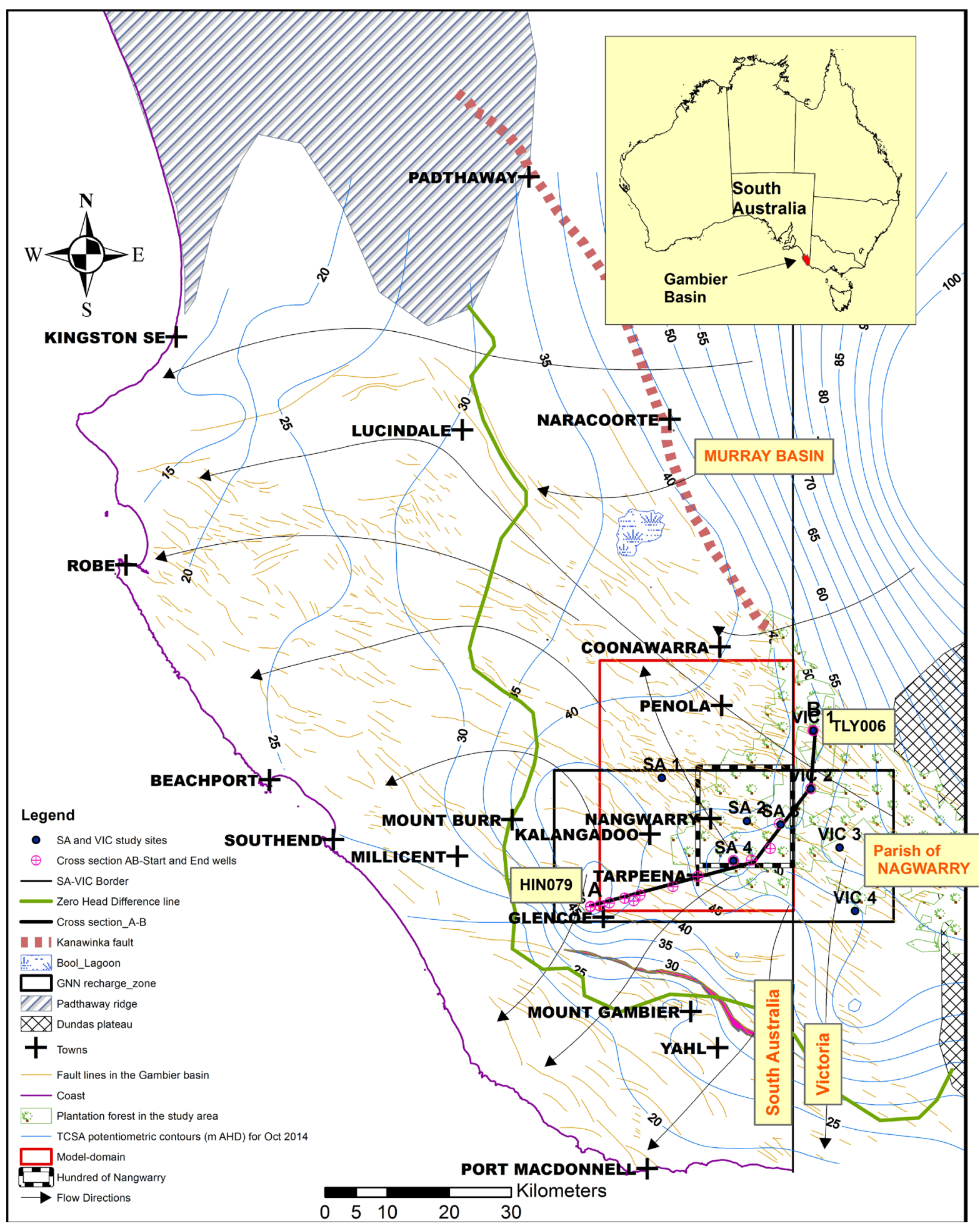

Figure 1. Gambier Basin and GNN recharge zone.

to erroneous predictions made by a model that is ostensibly "well calibrated”. Yeh et al. [29] recently addressed the uniqueness, scale, and resolution issues in groundwater flow models. They emphasized the need for full specifications of; flux boundaries, sources and sinks, and heads everywhere in the model domain, to obtain a unique solution to transient flow. The impracticality of such a requirement confirms the heuristic suggestion of Oreskes 
et al. [22].

Most recharge estimation efforts within the Gambier Basin [30]-[34] (Figure 1) have involved the shallow unconfined Tertiary limestone aquifer (TLA) as the TLA is the main source of irrigation, industrial, livestock and town water supplies. The Tertiary confined sand aquifer (TCSA) in the Gambier Basin is also an important groundwater resource that supplies good quality water to both urban and rural users, including water supplies to seven townships. Licensed groundwater extraction for irrigation in 2013-14 from the TCSA was $16 \times 10^{6} \mathrm{~m}^{3}$ [35]. Since the confined aquifers are sensitive to changes in flow rates that may result in excessive drawdowns, extraction practices or reduction in vertical leakage in recharge zones can have a detrimental effect on groundwater levels and water quality. To achieve sustainable groundwater management, it is necessary to understand how, and by how much, TCSA receives vertical leakage via diffuse and preferential flows from the overlying TLA through the aquitard.

Recharge to the TLA and vertical leakage to the TCSA has spatial and temporal variations. Relatively little work has been done on vertical leakage to the TCSA and no quantification of recharge in the GNN area has been completed. The present study adopts a heuristic approach for sub-regional estimate of vertical leakage through the aquitard. A groundwater flow model spanning the Glencoe and Nangwarry areas of the GNN recharge zone was developed to improve understanding of recharge to the TLA and vertical leakage to the TCSA aquifers and to assess the impact on the regional flow system.

\section{Hydrogeological Setting of the Model Domain}

Since a detailed description of the Gambier Basin and characteristics of the GNN recharge zone is given in Somaratne et al. [14], only a summary is provided here, focusing on features relevant to vertical leakage processes. The model domain spans parts of the Glencoe, Nangwarry and Penola areas (Figure 1). Numerous structural features occur within the model domain in terms of orientation and distribution of faults which are important elements for vertical leakage. Two major aquifer systems considered within the model are the TLA and the TCSA. Karstic features are common within the Gambier limestone, and it is a dual porosity system. Lithologies of the upper Tertiary aquitard overlying the TCSA are glauconitic and fossiliferous marls and clays of the Narawarturk Marl and clays of the Mepunga Formation [36]. The TCSA is a multi-aquifer system but due to the paucity of data, is treated as one aquifer unit. Since most of the wells drilled penetrate only the upper sand unit, hydraulic interconnection between the sub-aquifers is unknown [19].

The area is highly faulted. Groundwater bulging occurs in the TCSA within the GNN recharge zone, with dominant mounds at Glencore, SA 4 and VIC 3 sites (Figure 1), indicating that TCSA receives high vertical leakage. In this area, Love [36], Brown et al. [13] and Somaratne et al. [14] reported the presence of high percentages of radiocarbon activity indicating the TCSA receiving modern recharge. About $83 \%$ of the Hundred of Nangwarry area is covered with plantation forest, mainly Pinusradiata. In general, groundwater movement from the GNN recharge zone spreads outwardly in a northwesterly to southerly direction. The topography of the area is generally flat at about $70 \mathrm{~m}$ above Australian Height Datum (m AHD). The main geological units in a downward order consist of the unconfined TLA, Narawarturk Marl aquitard, Mepunga Formation, Dilwyn Clay aquitard and the TCSA (Figure 2).

Somaratne et al. [14] described eight investigation sites in this area; four (SA 1, SA 2, SA 3, SA 4) are located within the South Australian side of the GNN recharge zone and the rest (VIC 1, VIC 2, VIC 3, VIC 4) are located across the State boundary on the Victorian side (Parish of Nagwarry) of the recharge zone (Figure 1). The main features of the study sites include: the presence of Narawarturk Marl; $9 \mathrm{~m}$ thick at SA 3, $1 \mathrm{~m}$ thick at VIC 1, and at VIC 4 about $12 \mathrm{~m}$ thick; varying thickness of Mepunga Formation (4 - $12 \mathrm{~m}$ at SA sites and $1-12 \mathrm{~m}$ at VIC sites) and Dilwyn Clay aquitard (2 - $7 \mathrm{~m}$ at SA sites and 3 - $20 \mathrm{~m}$ at VIC sites). Overall, no aquitard occurs at VIC 3 (only $3 \mathrm{~m}$ Mepunga Formation separates TLA and TCSA) and while it is thickest at the VIC 4 site (26 m: 9 m Narawarturk Marl, 12 m Mepunga Formation and 5 m Dilwyn Clay). Apart from the SA 1, VIC 3 and VIC 4 sites, all sites are located within plantation forest.

The presence or absence of a competent aquitard and the head difference between the TLA and the TCSA determines the vertical leakage rate and is an important consideration in model conceptualization. In the southwest part of the GNN recharge zone, the Narawarturk Marl and Mepunga Formation are thin. For example at HIN079 both the Narawarturk Marl and Mepunga Formation are about $1 \mathrm{~m}$ thick, and the $12 \mathrm{~m}$ thick Dilwyn Clay aquitard is present. About $20 \mathrm{~m}$ uplift of all Formations is evident from drillhole 7022 - 8033 through to 


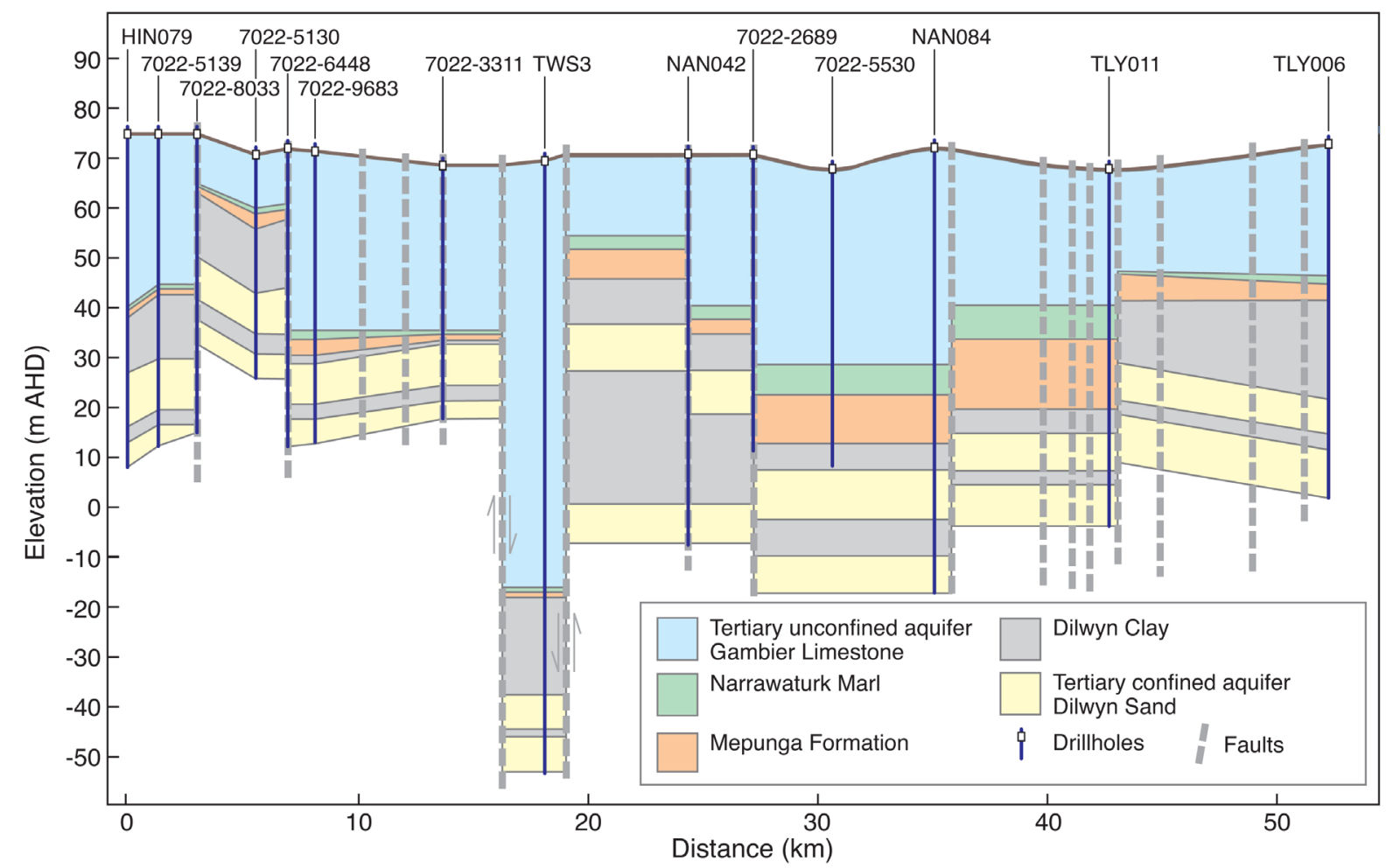

Figure 2. Conceptual geological cross section AB in Figure 1. Inferred fault displacements are shown in exaggerated vertical scale, at fault lines locations given in Figure 1 [14].

drillhole 7022 - 6448. A major displacement occurs between two fault lines east and west of TWS 3, the water supply well to the township of Kalangadoo. The thickest TLA is found at this location with thin Narawarturk Marl and Mepunga Formation. The area is identified as the Kalangadoo-Tarpeena fault zone. In this area the Narawarturk Marl and Mepunga Formations are about $1 \mathrm{~m}$ thick, while the Dilwyn Clay aquitard is about $20 \mathrm{~m}$ thick. Vertical displacement of the Formations combined with the thin aquitard favours relatively high direct recharge to the TCSA, as is evident in the presence of the groundwater mound in the Glencoe area (Figure 1). Towards the east of the Kalangadoo-Tarpeena fault zone, from NAN042 to NAN084 wells, a moderately thick Narawarturk Marl (3 - $7 \mathrm{~m}$ ) and Mepunga Formation (3 - $12 \mathrm{~m}$ ) are found. Monitoring well NAN042 is the TCSA well at study site SA 4 and is located on a fault line. Monitoring wells TLY011 and TLY006 are the TCSA wells at study sites VIC 2 and VIC 1. In this area once again, the thickness of the Narawarturk Marl (1 - 2 $\mathrm{m})$ and Mepunga Formation (3 - $5 \mathrm{~m}$ ) is reduced, but thick Dilwyn Clay (13 - $20 \mathrm{~m})$ is present. Investigation sites VIC 1 - 4 are outside the model domain.

\section{Methods}

The results from Somaratne et al. [14] show that TCSA receives both diffuse and preferential vertical leakage from the GNN recharge zone. A transient groundwater model previously developed in 2007 for the Nangwarry and Penola wellfield protection zone delineation is used to estimate recharge to the TLA and vertical leakage to the TCSA in the South Australian portion of the recharge zone. The model setup comprised two layers corresponding to TLA and TCSA with $100 \mathrm{~m} \times 100 \mathrm{~m}$ grid spacing, with 300 rows and 400 columns. The model is based on MODFLOW-2000 [37], and has a simulation period of 20 years from October 1985 to September 2005. Spatially interpolated cell-by-cell, initial head distributions were obtained by kriging of observed head values of monitoring wells. The model uses monthly stress periods to simulate temporal behaviour of well hydrographs. A quasi-three-dimensional approach [38] is adopted, where resistance to flow in low conductivity units (Narawarturk Marl, Mepunga Formation and Dilwyn Aquitard) is lumped together into a vertical leakance term between the adjacent layers and is represented by vertical flow only with no storage effects. Here, Mepunga Formation is a low yielding minor aquifer which has not been developed within the Gambier Basin, except at Kingston (Figure 1) 
town water supply. Horizontal flow may exist in the Mepunga Formation within the model domain, but is considered negligible compared to flows within the TLA and TCSA.

General head boundary (GHB) conditions of varying conductance were used around the model domain to represent the external hydrological conditions. External heads forcing flux into or out of the model domain at GHB boundaries were set according to time averaged groundwater levels outside the model domain. Conductance parameters along the GHB boundaries varied according to the updated hydraulic conductivity along boundary cells as the calibration progressed. Within the model area, hydrological stresses such as recharge, evapo transpiration and groundwater extraction were used. Layer elevations were defined using lithological information from drillholes within and surrounding area of the model domain; 120 drillholes were used for unconfined aquifer elevations, 108 for aquitard and 70 for TCSA. Once the layer elevations were identified, the next step in model setup was to define aquifer parameters; horizontal hydraulic conductivity $\left(K_{h}\right)$ for the TLA was obtained from three-pumping tests and 11 estimates based on specific capacity-transmissivity relation established by Mustafa and Lawson [39]. For TSCA, $K_{h}$ was available for nine locations from 72 hour pumping tests, and specific storage $\left(S_{s}\right)$ for two locations. The anisotropy for $K_{h}$ to $K_{v}$ (vertical hydraulic conductivity) of aquifers were taken as 10:1, for TLA and TCSA. For $K_{v}$ of the Dilwyn Clay aquitard hydraulic conductivity was estimated using particle size distribution data using the quasi-numerical model, ROSETTAV1 [40]. The core samples for analyses were taken from Nangwarry area, and show relatively high percentage of silt and sand (\% Clay $=32-42, \%$ of Silt $=20-53$, \% of Sand $=15-48$ ). For comparison, initial estimates of parameters, calibrated parameters and parameters derived from post-modelling pumping test conducted in 2011 within the recharge zone [41] are given in Table 1.

Apart from the town water supply wells, actual groundwater extractions volumes for irrigation were not available and therefore, licensed allocations of the irrigated areas were used. A total of $28 \times 10^{6} \mathrm{~m}^{3} \cdot \mathrm{year}^{-1} \mathrm{crop}$ area-water requirement (based annual allocations) were used as the groundwater extraction from the TLA aquifer at licensed property locations. About $26 \%$ of the model domain is covered with plantation forests; pine ( $\mathrm{Pi}$ nusradiata) and Tasmanian blue-gum (Eucalyptus globulus). Evapotranspiration (ET) is an important sink for shallow groundwater systems, and simulates the effects of plant transpiration, direct evaporation and removing water from the saturated groundwater regime. For shallow groundwater, evapotranspiration (ET) was represented using the EVT package of the MODFLOW. Tree and soil-based ET measurements have been undertaken by the former CSIRO Division of Forestry (Personnel communication with Richard Benyon, CSIRO) and ET data for the study was obtained for the Nangwarry plantation forests (Figure 3). For that part of the plantation forest burnt during the 1983 bush-fire, the year of canopy closure was taken as 1991. Effective rooting depth for plantation forest was set as $6 \mathrm{~m}$ [42].

For effective model calibration, it is essential to capture the spatial and temporal variation of recharge in the study area. An initial map of long-term recharge distribution was prepared using recharge values obtained by the water table fluctuation (WTF) method for 42 locations within and outside the study area. Recharge values ranged from 4 - $216 \mathrm{~mm} \cdot$ year $^{-1}$. The model area was divided into 11 recharge zones. Following Hanson et al. [43], a rainfall-recharge relationship was established with recharge as a percentage of infiltration of excess rainfall to the groundwater system. In the area, daily maximum ET for winter months is about $2 \mathrm{~mm}$ and for summer is about $5 \mathrm{~mm}$. In the study area, approximately $25 \mathrm{~mm}(6 \%)$ of monthly rainfall comprised of daily rainfall $<2$ mm during winter months and that for summer months, about $41 \mathrm{~mm}$ (23\%) of monthly rainfall comprised of

Table 1. Initial estimate, calibrated and post-modelling hydraulic parameters.

\begin{tabular}{|c|c|c|c|c|c|c|c|c|c|}
\hline \multirow{2}{*}{ Parameter } & \multicolumn{3}{|c|}{ TLA } & \multicolumn{3}{|c|}{ TCSA } & \multicolumn{3}{|c|}{ Aquitard } \\
\hline & $\begin{array}{c}\text { Initial } \\
\text { Estimates }\end{array}$ & $\begin{array}{c}\text { Calibrated } \\
\text { Values }\end{array}$ & $\begin{array}{l}\text { Post-modelling } \\
\text { in } 2011\end{array}$ & $\begin{array}{c}\text { Initial } \\
\text { Estimates }\end{array}$ & $\begin{array}{l}\text { Calibrated } \\
\text { Values }\end{array}$ & $\begin{array}{l}\text { Post-modelling } \\
\text { in } 2011\end{array}$ & $\begin{array}{c}\text { Initial } \\
\text { Estimates }\end{array}$ & $\begin{array}{l}\text { Calibrated } \\
\text { Values }\end{array}$ & $\begin{array}{l}\text { Post-modelling } \\
\text { in } 2011\end{array}$ \\
\hline$K_{h}(\mathrm{~m} /$ day $)$ & $11-31.3$ & $15-40$ & & $2-79$ & $12-55$ & $32-123$ & & & \\
\hline$S_{y}$ & $0.1-0.15^{*}$ & $0.13-0.19$ & & - & - & - & & & \\
\hline$S_{s}(1 / \mathrm{m})$ & - & - & - & 0.0001 & $0.0006-0.002$ & $0.0007-0.0023$ & & & \\
\hline$K_{v}(\mathrm{~m} /$ day $)$ & - & - & - & - & - & - & $\begin{array}{c}0.0207 \text { - } \\
0.664\end{array}$ & $\begin{array}{l}1 \times 10^{-6} \\
-0.022\end{array}$ & $\begin{array}{c}0.00031 \text { - } \\
0.0027\end{array}$ \\
\hline
\end{tabular}

*From pumping tests outside the model domain; Post modelling data in 2011 for TCSA recharge zone at SA 1 - 4 sites. 


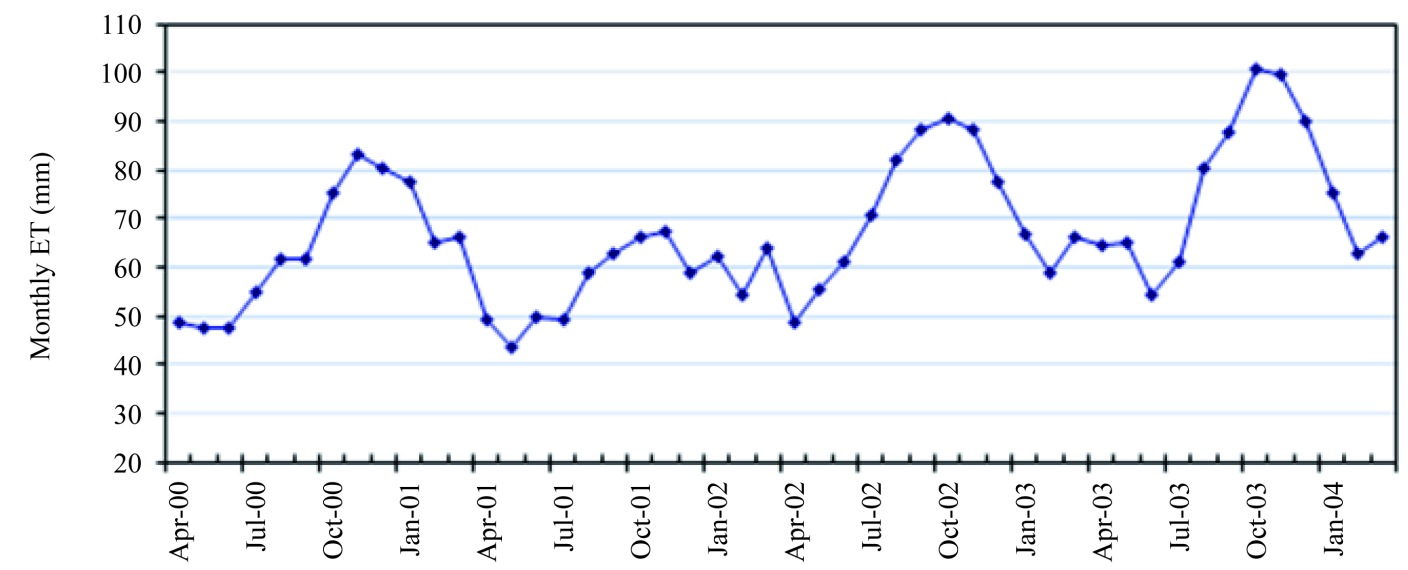

Figure 3. Monthly ET for Nangwarry forest (CSIRO unpublished data, Richard Benyon).

daily rainfall $<5 \mathrm{~mm}$. It is considered that daily rainfall less than daily ET would not contribute to soil infiltration. These rainfall threshold limits were deducted from respective winter and summer monthly rainfall to obtain monthly excess rainfall, and a fraction of that would potentially contribute to recharge.

Therefore, a monthly recharge estimate is obtained from:

$$
\mathrm{RCH}=\left(\mathrm{R}_{\text {Month }}-\mathrm{R}_{\text {Threshold }}\right) x
$$

where RCH is the monthly recharge, $\mathrm{R}_{\text {Month }}$ is the monthly rainfall, $\mathrm{R}_{\text {Threshold }}$ is the threshold rainfall and, $x$ is the fraction (\%) that would recharge. The percentage $(x)$ is determined through trial-and-error model calibration for different recharge zones. The calibrated $x$ values range from 5\% for Penola forest to $85 \%$ at Glencoe groundwater mound area, maintaining the recharge range obtained using the WTF method.

One of the important issues considered in model calibration is to limit the number of parameters to be estimated without losing too much of the spatial variability of parameters derived from pumping tests and recharge estimates from the WTF method. The exception to this is groundwater mounds locations in the TCSA and locations of major faults. For parameters and recharge, the well-established zonation approach was adopted [44] [45]. The model was calibrated to represent observed areal head distributions and the well hydrograph response due to natural and seasonal variation, ET and pumping stresses at specific sites. The calibration procedure involved modifying specific yield, specific storage, vertical leakance and horizontal hydraulic conductivity to improve regional hydraulic gradient and potentiometric contour patterns.

\section{Results and Discussion}

\subsection{Transient Model Calibration}

The calibrated groundwater potentiometric heads for the end stress period were compared with the measured heads and are shown in Figure 4(a) and Figure 4(b).

Model performance can be examined more rigorously by analysing the hydrographic responses at specific sites. At this stage aerially calibrated hydraulic conductivity and specific yields/storage were used as the initial parameter values. Local changes were made to parameters to reflect the hydraulic gradients and observed bore hydrographs. Following this, once again, parameter values were re-calibrated to match potentiometric contours. This iterative process continued until satisfactory areal and bore hydrograph calibration was achieved. Calibrated bore hydrographs within plantation forests and irrigation areas are depicted in Figure 5 and Figure 6.

We calibrated all long-term data available from monitoring wells in the model domain. Twelve monitoring wells were used within the plantation forest for TLA calibration. Apart from the PEN002 and PEN011 wells, which are influenced by groundwater extraction from adjacent irrigation areas, the observed seasonal range of water level fluctuations within the plantation forest were minor, and long-term observed and calculated water level decline agree reasonably well. In contrast, observed groundwater level fluctuations vary substantially in the irrigation area (Figure 6) as some of the pumping wells are being used as head observation wells (Figure 7), thus reducing the credibility of these observations. 


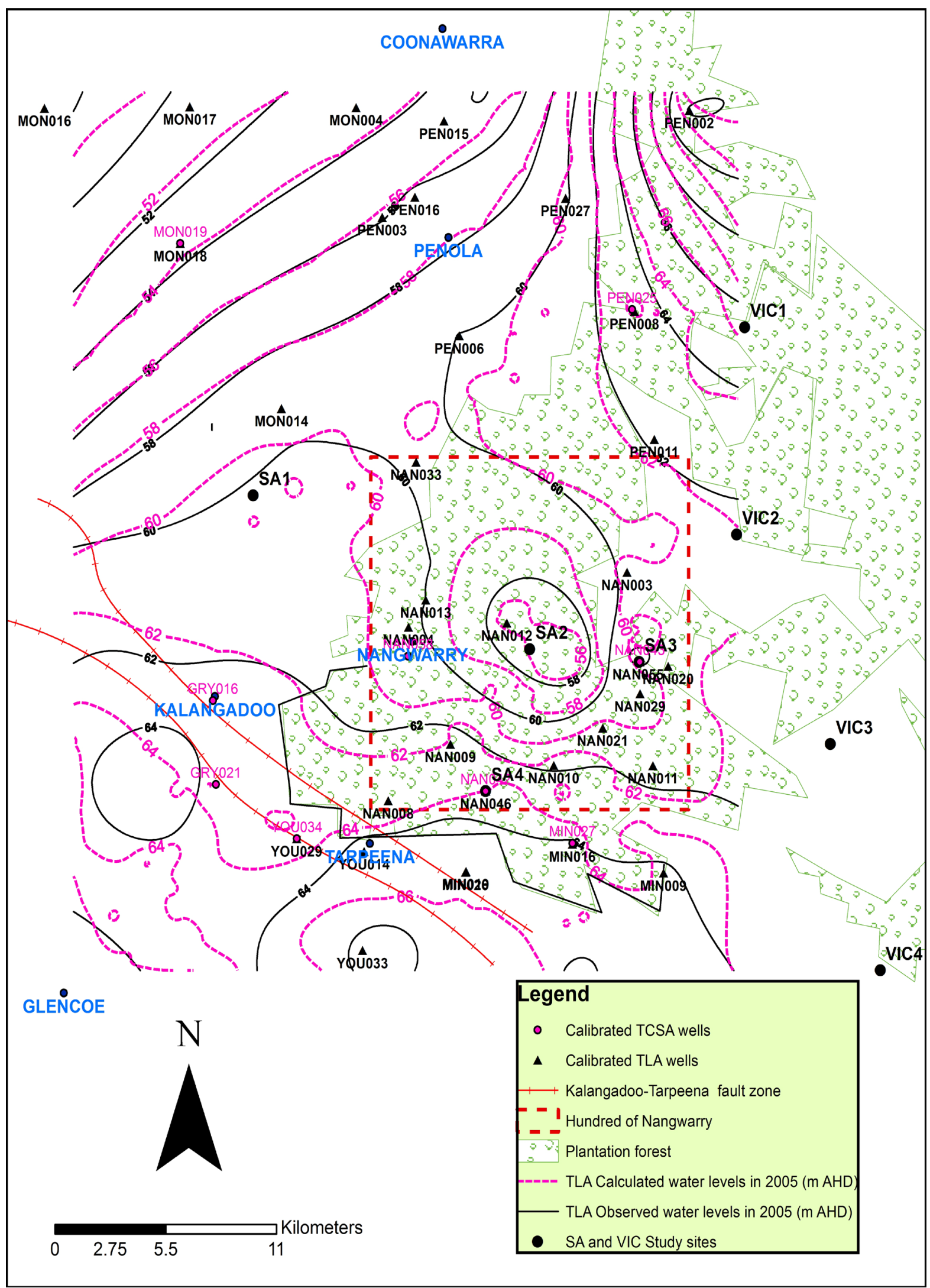




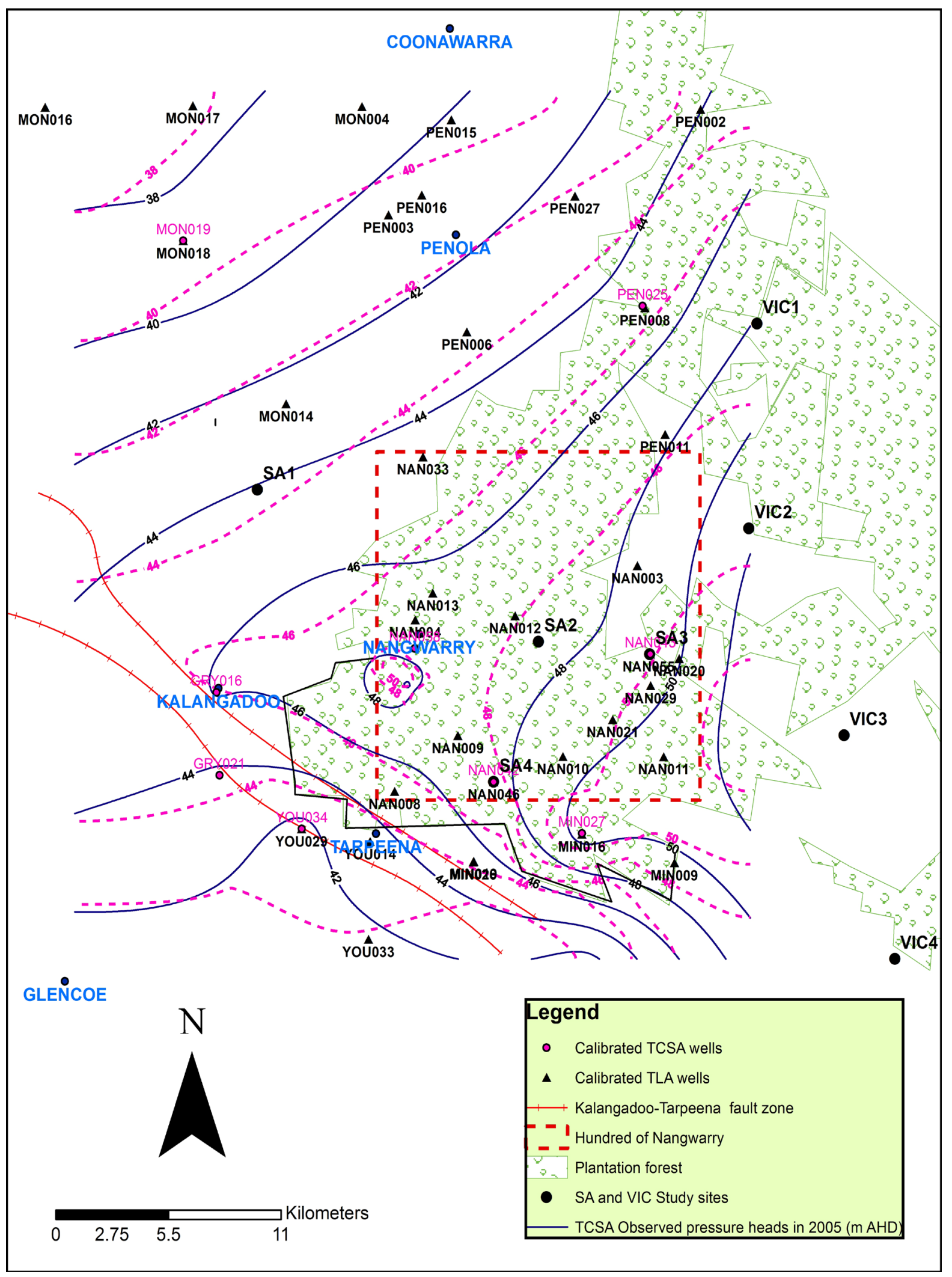

(b)

Figure 4. Areal calibration of the model (a) TLA; (b) TCSA. 

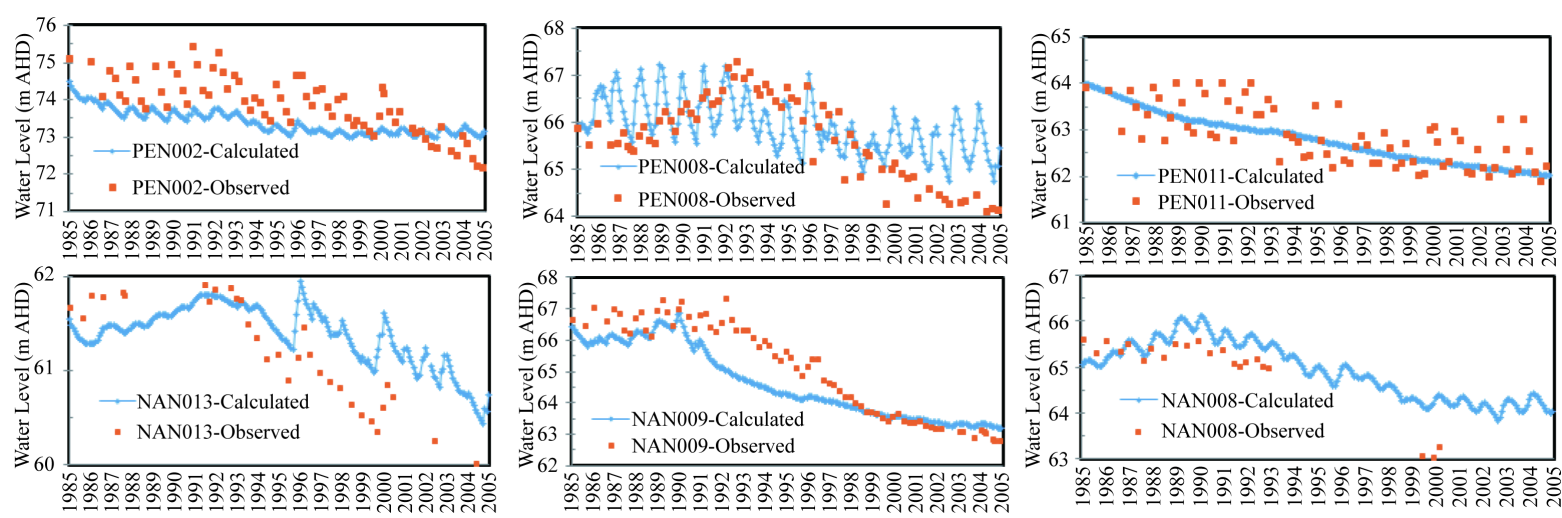

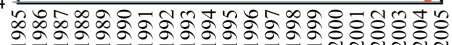

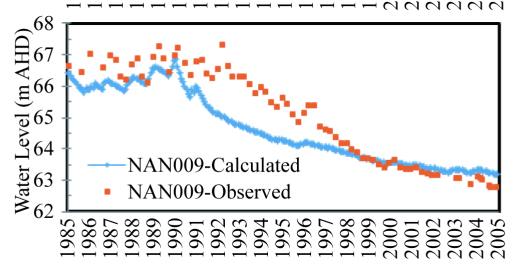

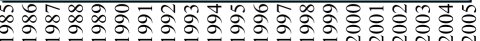
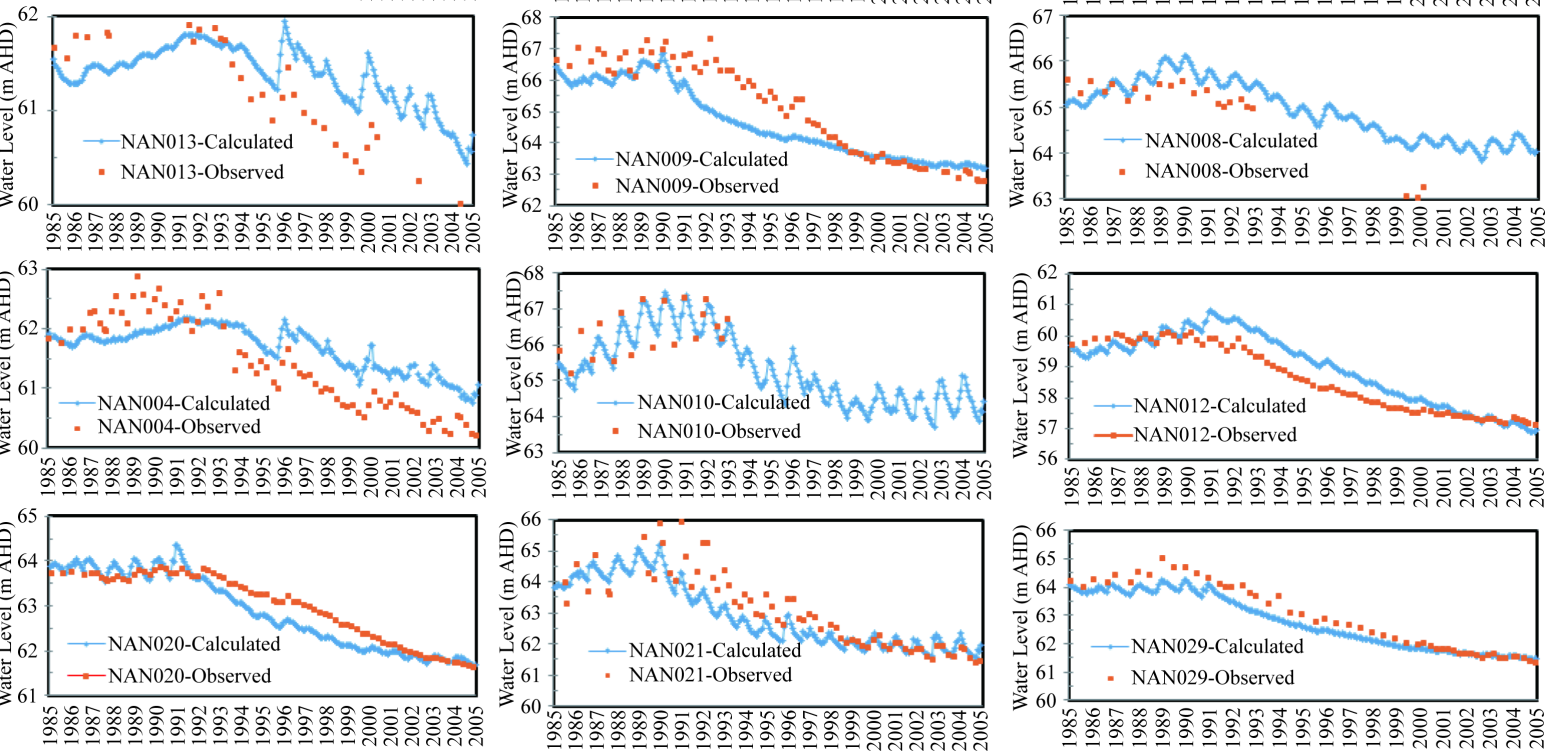

Figure 5. Observed and calculated TLA well hydrographs in the plantation forest area of the model domain.
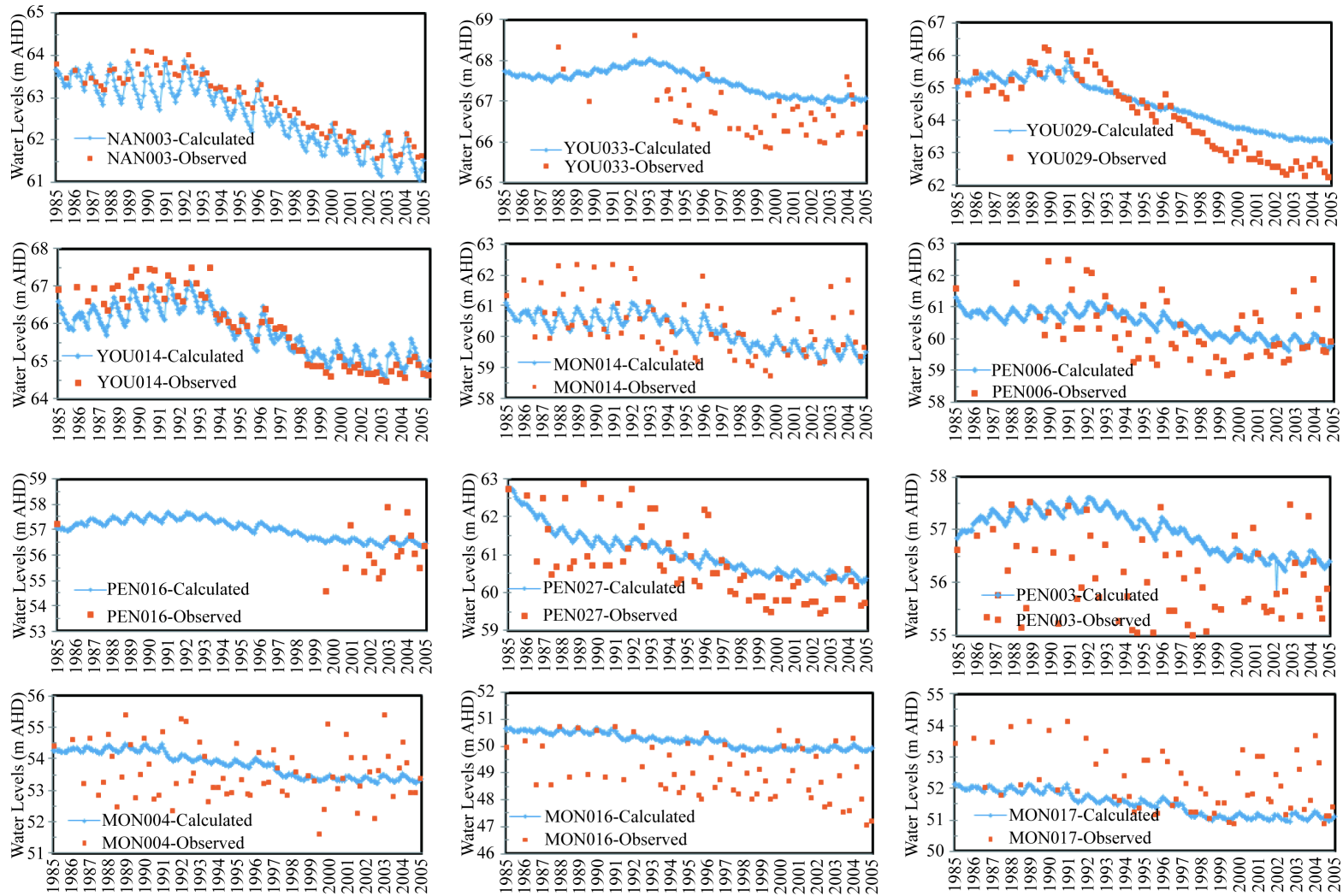

Figure 6. Observed and calculated TLA well hydrographs in the irrigation area of the model domain 
When low credibility observations are present, difficulties arise as to overall model calibration. One problem is that time series do not display distinct seasonal and annual variations. This is further exacerbated due to water level monitoring undertaken twice per year, in summer and winter, yielding water level data with extreme values. Therefore, we attempted to calibrate the "average long-term trend" of the water table fluctuations of observed time series.

Paired TLA-TCSA wells, located close to each other, were calibrated to obtain reliable vertical leakage to the TCSA (Figure 8). Wells PEN008-PEN025 are located in the Penola forest; NAN055-NAN043 and NAN046NAN042 are located in the Nangwarry forest. MON18-MON019 (Monbulla area), YOU029-YOU034 (Young area) and MIN016-MIN027 (Mingbool area) were available and used for irrigation areas. Apart from the over prediction at NAN042, head differences were reasonably well simulated through the modelling process.

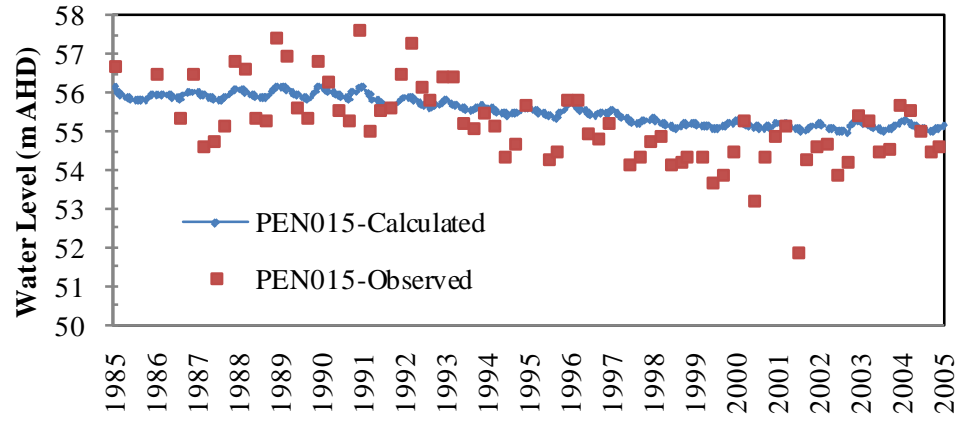

(a)

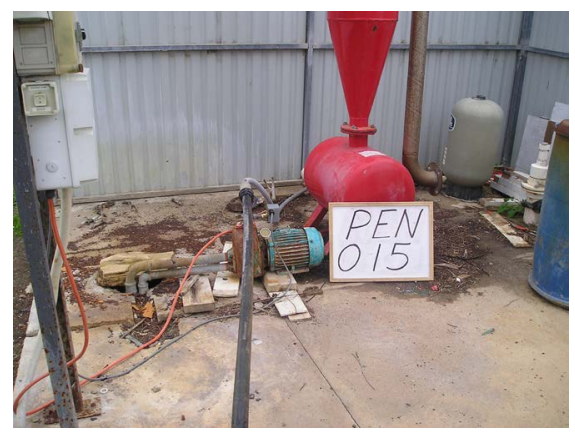

(b)

Figure 7. (a) Observed and calculated well hydrographs; (b) Pump house of the monitoring well use for irrigation water supply.
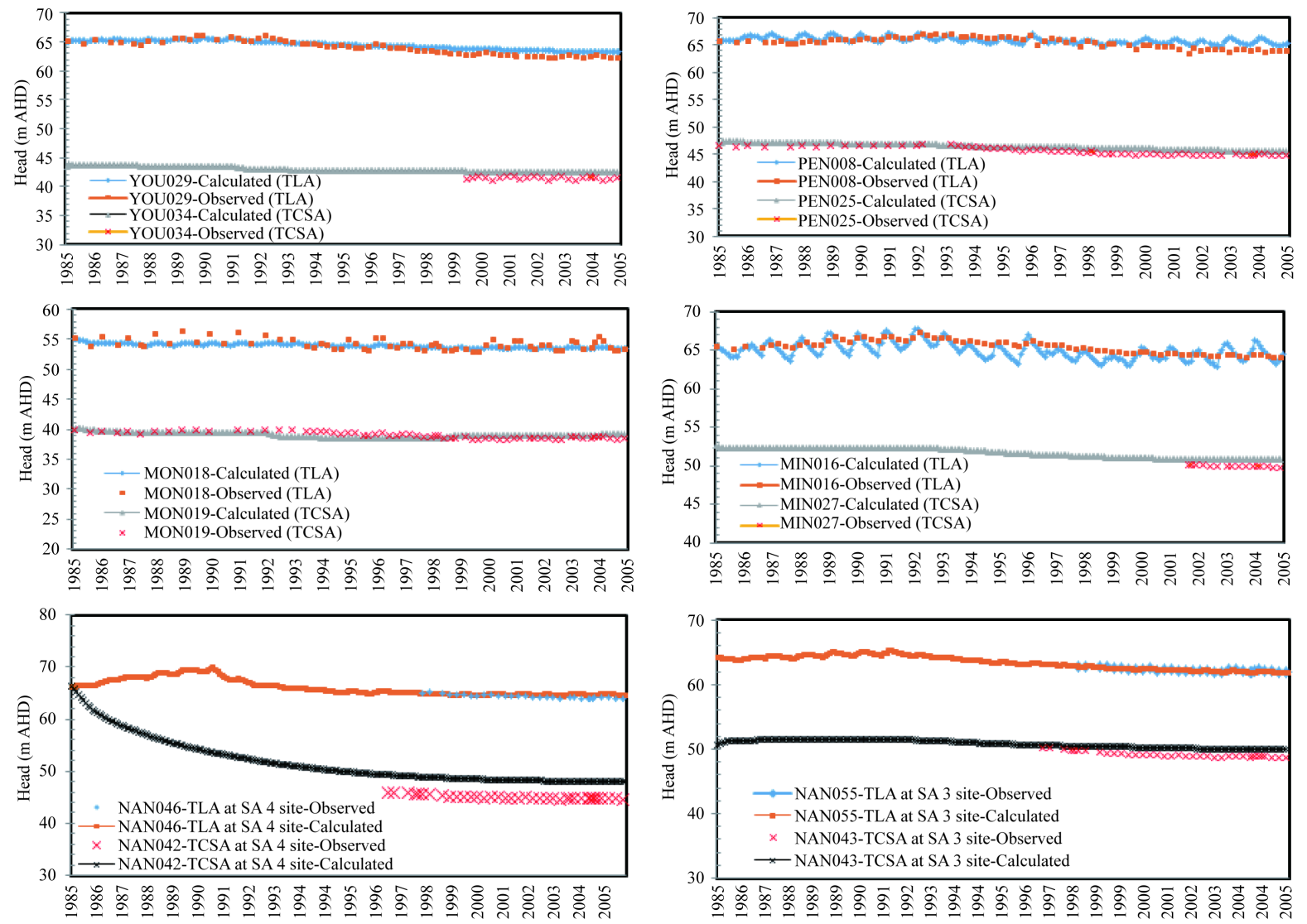

Figure 8. Calibration of hydrographs for vertical recharge to TCSA. 
Despite the groundwater mound in the Glencoe area spanning from Glencoe to Kalangadoo in the GNN recharge zone (Figure 1), no paired wells are currently available in the entire western region. Two TCSA wells in the Kalangadoo-Tarpeena fault zone were calibrated (Figure 9), but once again head-observations from these wells are of low credibility as GRY021 is equipped with a submersible pump and used for irrigation and livestock watering. The well GRY016 is currently backfilled and replaced, but was the water supply well for the Kalangadoo township during the study period. This Glencoe to Kalangadoo portion of the model heavily depended on areal calibration of head contours in the TCSA.

Quantitative calibration performance measures can be related to calculation of potentiometric head residuals and associated statistics. Figure 10 shows the scatter plot of calculated versus observed groundwater heads for TLA and TCSA. The total number of observations for the 20-year simulation is 2375 .

Small positive skewness $(0.2 \mathrm{~m})$ close to zero is considered a reasonable calibration with a root mean squared error (RMSE) of $0.83 \mathrm{~m}$. The normalized RMSE (expressed in \%) is considered a more representative measure of fit since it accounts for the scale of the potential range of data values [46], which is $2.2 \%$ in our case. In general, a normalized RMSE value less than $5 \%$ is considered a good fit between calculated and observed values. The correlation coefficient of the observed heads to calculated heads in this calibration is 0.995 , indicating that the two range of data (calculated and observed) move together.

Sensitivity analyses were carried out to explore and quantify the impact of possible errors in input data on model performance indices. This also can be used to provide a first order uncertainty analysis [47]. Sensitivity analyses for the key parameters, $K_{h}, K_{v}, S_{y}, S_{s}$, and recharge were undertaken. Each set of values was altered separately by increasing and decreasing the calibrated parameter value using multiplication factors between 0.1 and 10 . The parameter multiplier is spatially and temporally constant. The results of sensitivity analyses show hydraulic conductivity and recharge to TLA are most sensitive (Figure 11). The key hydraulic parameters determined during the post-modelling period in 2011 are in good agreement with the range of values obtained from model calibration (Table 1). The exception to this finding is the increased $K_{v}$ of the aquitard at locations of faults and groundwater mounds in the Nangwarry and Glencoe areas.
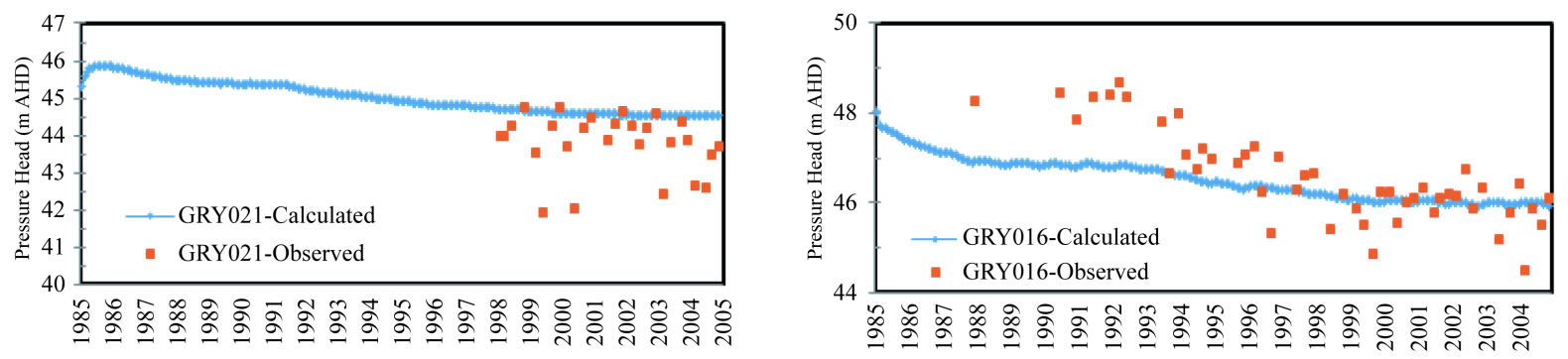

Figure 9. Observed and calculated well hydrographs in the TCSA.

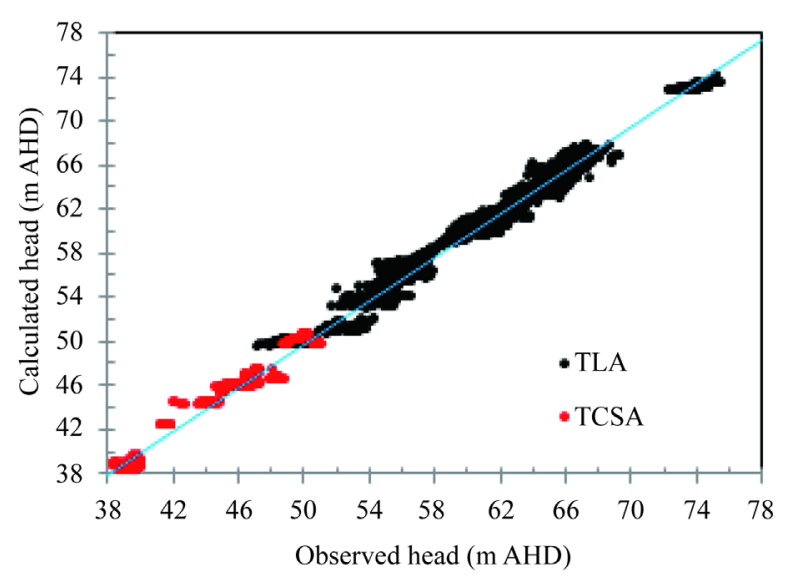

(a)

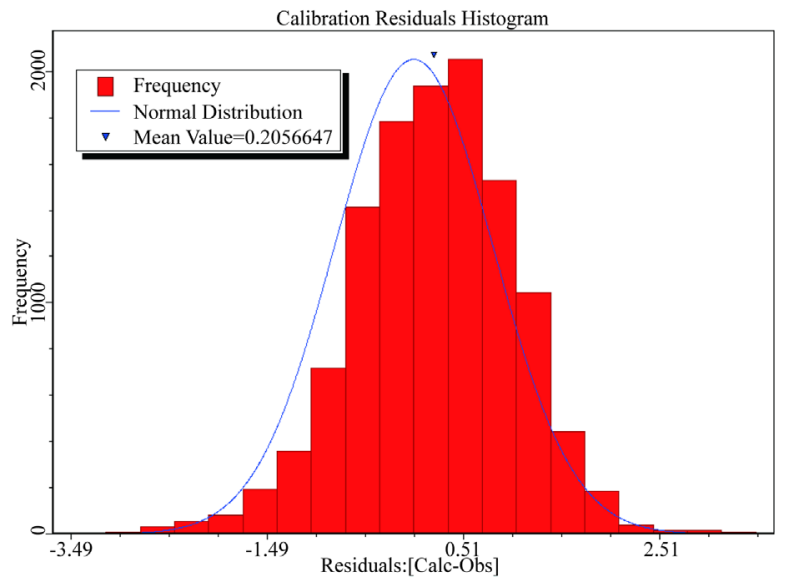

(b)

Figure 10. Calibration statistics: (a) Calculated vs Observed water levels; (b) Calibration residual histogram. 


\subsection{Water Balance}

Figure 12 shows the transient water balance for the TLA aquifer. Recharge to the aquifer varies significantly, 0 - $2677 \mathrm{~m}^{3} \cdot$ day $^{-1}$, with an average $455 \mathrm{~m}^{3} \cdot \mathrm{day}^{-1}$. The highest recharge occurred in response to June 2003 monthly rainfall of $184.6 \mathrm{~mm}$, about $30 \%$ of the average annual rainfall in the area. Since recharge is a function of monthly rainfall this variation is expected. In response to the rise and fall of water levels, TLA storage changes with a net average depletion of $47 \mathrm{~m}^{3} \cdot \mathrm{day}^{-1}$. Other flow components of the water balance include: leakage to TCSA $\left(297 \pm 11 \mathrm{~m}^{3} \cdot\right.$ day $\left.^{-1}\right)$, well extraction $\left(79 \mathrm{~m}^{3} \cdot\right.$ day $\left.^{-1}\right)$, ET $\left(36 \mathrm{~m}^{3} \cdot\right.$ day $\left.^{-1}\right)$ and net boundary flow out from the domain at $79 \mathrm{~m}^{3} \cdot$ day $^{-1}$, all of which remained relatively stable over the study period.
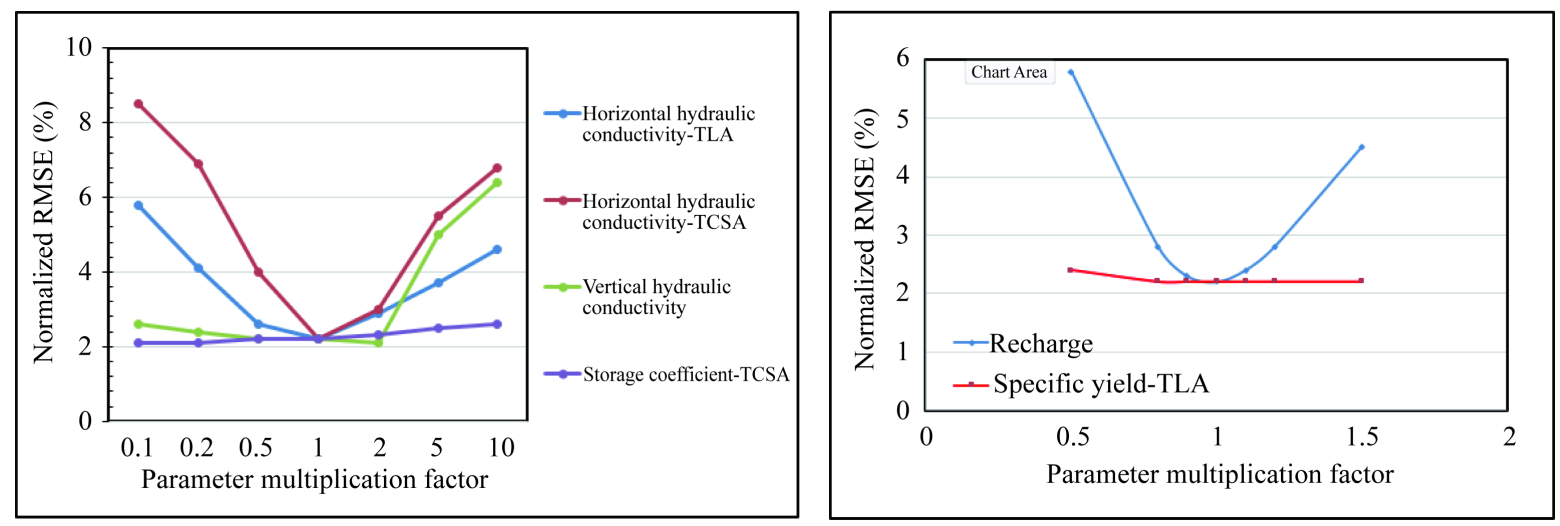

Figure 11. Sensitivity analyses: Normalized RMSE vs parameter multiplication factor.

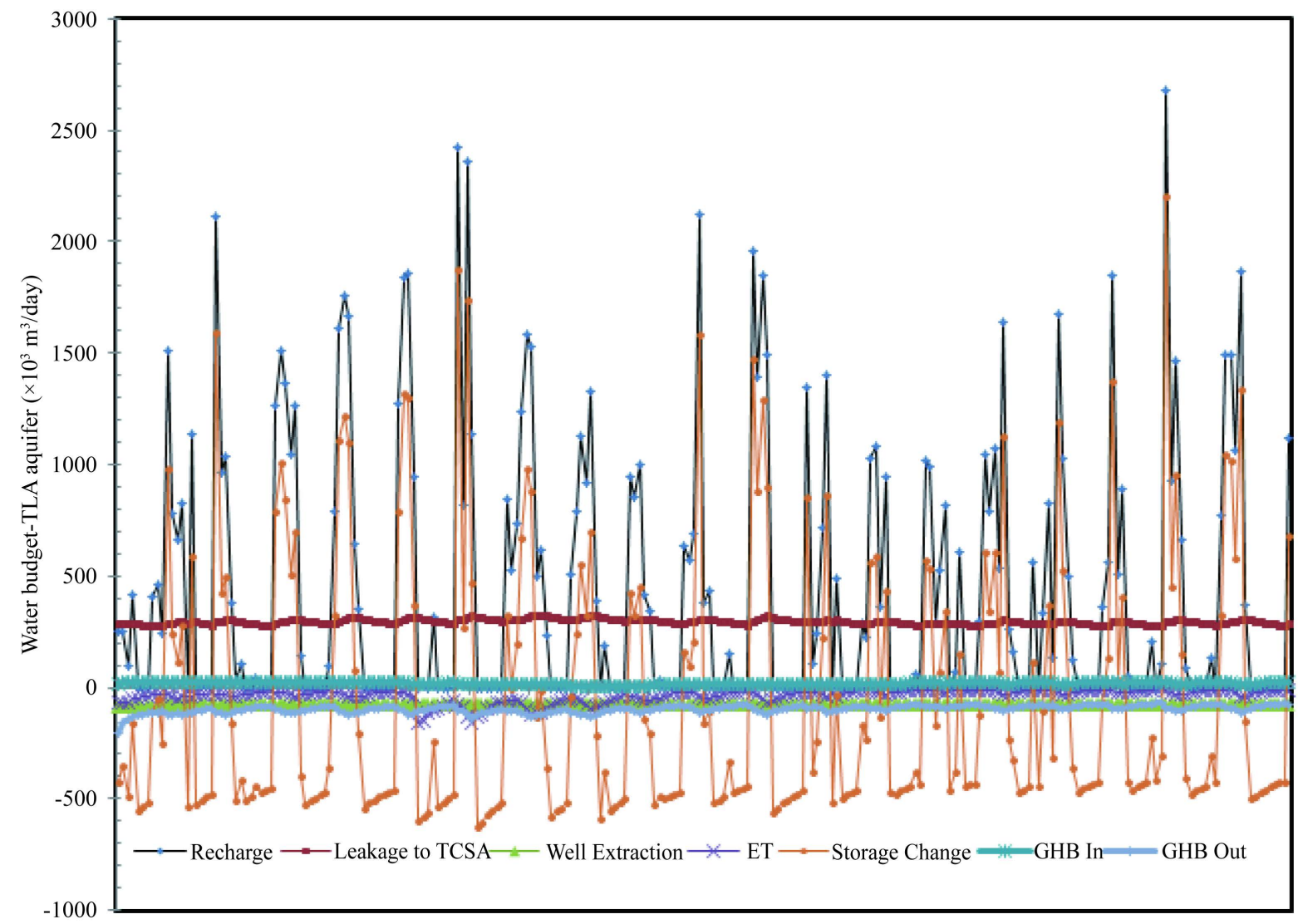

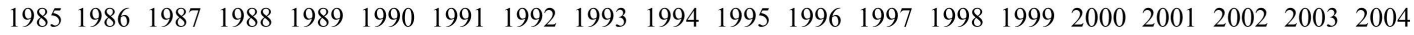

Figure 12. Transient water balance for the TLA. 
Recharge to TLA and vertical leakage to TCSA was assessed on the basis of the water balance of management areas of the water allocation plan (WAP) for comparison with WAP recharge (Figure 13). Recharge for the current WAP was assessed using the WTF method [48] except for the Hundred of Young, which is based on previous studies [48] using environmental chloride and tritium. For simplicity, a specific yield value of 0.1 was taken for recharge estimation for the WAP.

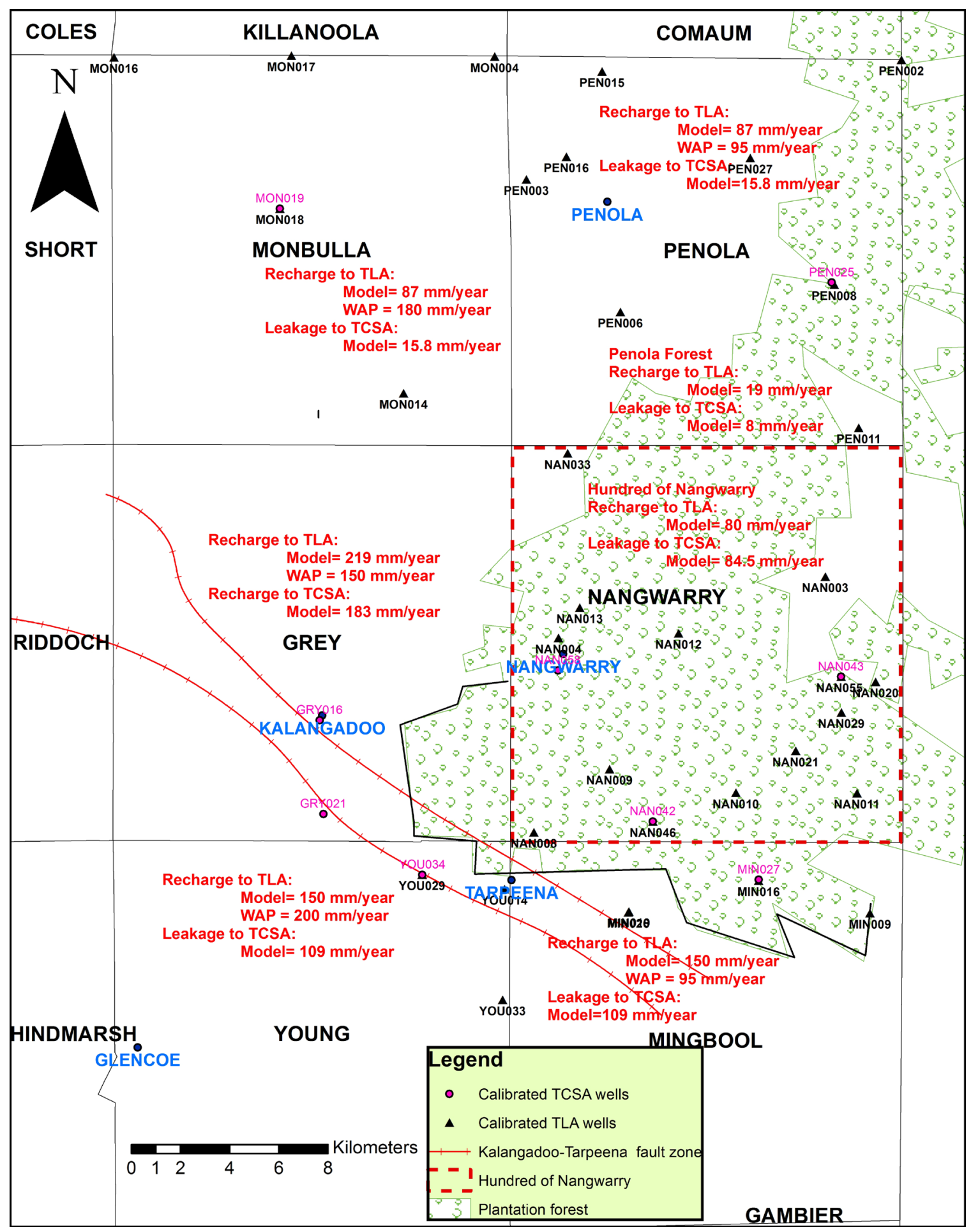

Figure 13. Recharge to TLA and vertical leakage to TCSA. 
WAP adopted recharge for Penola, Monbulla and Young are higher than the recharge from the calibrated model. For the Hundred of Grey, a single monitoring well was used to calculate a recharge at $150 \mathrm{~mm} \cdot \mathrm{year}^{-1}$ for the WAP [48], while the model calculated recharge from areal calibration of $219 \mathrm{~mm} \cdot$ year $^{-1}$. Model calculated recharge ( $\left.150 \mathrm{~mm} \cdot \mathrm{year}^{-1}\right)$ for the irrigation areas of Young and Mingbool are equal since a single water balance zone was used in the model.

For the non-forested area of the Hundred of Penola, the model calculated an annual recharge of $87 \mathrm{~mm} \cdot \mathrm{year}^{-1}$, while for the Penola forest recharge was calculated at $19 \mathrm{~mm} \cdot \mathrm{year}^{-1}$ for TLA. When compared to non-forested areas, a recharge reduction of $78 \%$ is observed for the Penola forest. Despite the fact that $83 \%$ of the Hundred of Nangwarry is covered with plantation forest, a comparatively high recharge $\left(80 \mathrm{~mm} \cdot \mathrm{year}^{-1}\right)$ to TLA is calculated by the model. This represents $44 \%$ less recharge than adjacent non-forested areas within the Hundred of Nangwarry. Both Penola and Nangwarry areas are faulted (Figure 1).

The hydrogeological difference between Penola and the Nangwarry forest is the presence of preferential flow paths via a generally thin aquitard in Nangwarry. In contrast, Penola and Monbulla have about a $50 \mathrm{~m}$ thick aquitard layer (combined Narawarturk Marl, Mepunga Formation and Dilwyn Clay) separating the TCSA from the TLA. This indicates that the influence of structural faults is effective only in areas where the aquitard is thin or absent [14]. As such, the model calculates $8 \mathrm{~mm} \cdot$ year $^{-1}$ vertical leakage to TCSA in the Penola forested area, compared to $84.5 \mathrm{~mm} \cdot$ year $^{-1}$ vertical leakage in the Nangwarry forested area. One point to note is that the model results show leakage to TCSA as higher $\left(84.5 \mathrm{~mm} \cdot \mathrm{year}^{-1}\right)$ than the recharge to TLA $\left(80 \mathrm{~mm} \cdot \mathrm{year}^{-1}\right)$ in the Hundred of Nangwarry. This, results in a continuous decline of water levels in TLA. Combined with a groundwater loss to ET $\left(13 \mathrm{~mm} \cdot \mathrm{year}^{-1}\right)$ from areas where depth to water $<6 \mathrm{~m}$, this would result in the TLA beginning to dry up. This phenomenon appears to be happening at investigation site SA 2 [14].

Our results compare favourably with research indicating that groundwater recharge under Pinusradiata plantations is either zero [30] [31] [49] or substantially lower than under grassland [32]. Direct measurements of water use by plantations confirm recharge is usually zero after canopy closure [42] [50] [51]. However, the above cited studies either, do not consider preferential recharge to groundwater or used measurements made outside the GNN recharge zone. Compared to the average recharge from agricultural lands, Benyon and Doody [42] estimate that the reduction of recharge under Pinusradiata is about $85 \%$ and under Eucalyptus globlus about $78 \%$. The model calculated a recharge reduction of $78 \%$ in Penola forest, where the recharge process is predominantly diffuse.

As noted by Bevan and Young [52], forecasting future management conditions is heavily reliant on several assumptions, particularly those related to rainfall dependent recharge, groundwater use and other land use practices. Therefore, "what-if" scenarios or projections were considered to further assess the impact of land use on groundwater recharge. A simulation of replacing plantation forest with dryland pasture in the Hundred of Nangwarry area for the calibration period resulted in recharge to TLA of approximately $135 \mathrm{~mm} \cdot \mathrm{year}^{-1}$ and leakage to TCSA, of $98 \mathrm{~mm} \cdot$ year $^{-1}$.

With respect to replicating head contours and observed time series, the performance of our model may be considered appropriate for assessing vertical leakage to TCSA and the impact of the plantation forest on groundwater recharge. One of the major difficulties in model construction was to assign reliable $K_{v}$ distributions, since the only data sets available at the time, were particle size distribution based estimated values (Table 1) and aquitard hydraulic conductivity (range $10^{-3}-10^{-7} \mathrm{~m} \cdot$ day $^{-1}$ ) obtained from triaxial tests [36]. In addition, the ranges of transmissivity for TLA $\left(200-10,000 \mathrm{~m}^{2} \cdot \mathrm{day}^{-1}\right)$ and TCSA $\left(200-1600 \mathrm{~m}^{2} \cdot \mathrm{day}^{-1}\right)$ in the Gambier Basin [36] were used as a guide. Despite the calibration approach chosen, vertical leakage is truly vertical only if; the head in the layer supplying the leakage is constant, and if permeability contrasts in the aquitard and confined aquifer, and storage in the aquitard layer are negligible [53]. These assumptions may not fully hold in the GNN recharge zone. Harrington and Cook [54] highlight the needs for applying correction for measured confined aquifer pressure levels for the mechanical loading and unloading effect of the watertable levels in overlying unconfined aquifer. The study of Harrington and Cook [54] shows that the maximum possible loading/unloading impact on a confined aquifer can only be a fraction of the observed watertable fluctuation of the unconfined aquifer, equivalent to the specific yield. In this study, TCSA head corrections were not made and hence calculated pressure levels may include smaller over and under estimation than actually observed.

The use of groundwater allocation as actual extraction is another source of error. During the post modelling period, metered annual extraction data were available for the model area. Compared to the 2013-2014 irrigation season, actual groundwater extraction is $69 \%$ of the area-based annual allocation. This means an excess of 8.68 
$\times 10^{6} \mathrm{~m}^{3}$ of water was extracted in the TLA water balance, which results in higher calculated recharge. Distribution of estimated excess volumes across the total irrigation area, $970 \mathrm{~km}^{2}$, results in approximately $9 \mathrm{~mm}$ over estimation of recharge to TLA.

\section{Conclusions}

A groundwater flow model spanning the Glencoe and Nangwarry areas of the GNN recharge zone was developed to improve understanding of vertical recharge to the TLA and TCSA aquifers and to assess the impact on the regional flow system. The model was developed using MODFLOW-2000 with a calibration period from October-1985 to September-2005. Despite many studies considering the importance of vertical leakage to the confined aquifer, and the impact of plantation forestry on groundwater recharge, quantification of vertical leakage to the confined aquifer was lacking.

The model calculated recharge to the confined aquifer in diffuse recharge zone under plantation forest (Penola forest) of about $8 \mathrm{~mm} \cdot \mathrm{year}^{-1}$, a 78\% reduction of recharge compared to adjacent non-forest areas. Where structural uplift and geological faults are present as in Hundred of Nangwarry, vertical leakage is about $84.5 \mathrm{~mm} \cdot \mathrm{year}^{-1}$. The higher recharge is attributed to the thin or absent aquitard and preferential flow through faults. The results gained in this study show that a change to lower water use land use in the GNN recharge zone can potentially increase recharge; $68 \%$ increase in the TLA and $16 \%$ to the TCSA. The effect of preferential flow on recharge to the unconfined aquifer and vertical leakage to the confined aquifers was unknown in the GNN recharge zone. In the absence of any other suitable techniques, we show that first order assessment of the recharge and vertical leakage can be assessed by sub-regional water balance estimates using a calibrated groundwater model. Management of the entire GNN recharge zone based on these new results is the key to ensuring the sustainability of the TCSA.

\section{Acknowledgements}

The editor and reviewers are thanked for evaluating the manuscript. We thank Glyn Ashman for manuscript review.

\section{References}

[1] Sukjija, B.S., Reddy, D.V., Nagabhushanam, P., Hussain, S., Giri, V.Y. and Patil, D.J. (1996) Environmental and Injected Tracers Methodology to Estimate Direct Precipitation Recharge to a Confined Aquifer. Journal of Hydrology, 77, 77-97. http://dx.doi.org/10.1016/0022-1694(95)02788-2

[2] Jones, B.F., Hanor, J.S. and Evans, R.W. (1994) Sources of Dissolved Salts in the Central Murray Basin, Australia. Chemical Geology, 111, 135-154. http://dx.doi.org/10.1016/0009-2541(94)90087-6

[3] Hendry, M.J., Wassenaar, L.I. and Kotzer, T. (2000) Chloride and Chlorine Isotopes $\left({ }^{36} \mathrm{Cl}\right.$ and $\left.\delta^{37} \mathrm{Cl}\right)$ as Tracers of Solute Migration in a Thick, Clay-Rich Aquitard System. Water Resources Research, 36, 285-296. http://dx.doi.org/10.1029/1999WR900278

[4] Love, A., Herczeg, A.L. and Walker, G. (1995) Transport of Water and Solutes across a Regional Aquitard Inferred from Porewater Deuterium and Chloride Profiles Otway Basin, Australia. In: IAEA (Ed.), Proceedings of a Symposium on Isotopes in Water Resources Management, Vienna, 20-24 March 1995, Vol. 1: 73-86.

[5] Harrington, G.A., Walker, G.R., Love, A.J. and Narayan, K.A. (1999) A Compartmental Mixing-Cell Approach for the Quantitative Assessment of Groundwater Dynamics in the Otway Basin, South Australia. Journal of Hydrology, 214, 49-63. http://dx.doi.org/10.1016/S0022-1694(98)00243-1

[6] Motz, L.H. (1998) Vertical Leakage and Vertically Averaged Vertical Conductance for Karst Lakes in Florida. Water Resources Research, 34, 159-167. http://dx.doi.org/10.1029/97WR03134

[7] Ruhl, J., Kanivetsky, R. and Shmagin, B. (2002) Estimates of Recharge to Unconfined Aquifers and Leakage to Confined Aquifers in the Seven-County Metropolitan Area of Minneapolis-St. Paul, Minnesota. Water Resources Investigation Report 2002-4092, US Geological Survey, Minnesota.

[8] Chen, C. and Jiao, J.J. (1999) Numerical Simulation of Pumping Tests in Multilayer Wells with Non-Darcian Flow in the Wellbore. Groundwater, 37, 465-474. http://dx.doi.org/10.1111/j.1745-6584.1999.tb01126.x

[9] Neuman, S.P. and Witherspoon, P.A. (1968) Theory of Flow in Aquicludes Adjacent to Slightly Leaky Aquifers. Journal of Water Resources Research, 4, 103-112. 
[10] Cihan, A., Zhou, Q. and Birkhlzer, J.T. (2011) Analytical Solutions for Pressure Perturbations and Fluid Leakage through Aquitards and Wells in Multi Layered Aquifer Systems. Water Resources Research, 47, WR10504. http://dx.doi.org/10.1029/2011WR010721

[11] Somaratne, N. (2014) Characteristics of Point Recharge in Karst Aquifers. Water, 6, 2782-2807.

[12] Somaratne, N. (2015) Pitfalls in Application of the Conventional Chloride Mass Balance (CMB) in Karst Aquifers and Use of the Generalized CMB Method. Environmental Earth Sciences, 74, 337-349.

[13] Brown, K.G., Love, A.J. and Harrington, G.A. (2001) Vertical Groundwater Recharge to the Tertiary Confined Sand Aquifer, South East, South Australia. Report DWR 2001/002, Department for Water Resources, Adelaide.

[14] Somaratne, N., Lawson, J. and Mustafa, S. (2015) Study of Characteristics of the Recharge Zone and Groundwater Movement in the Tertiary Confined Sand Aquifer for the Establishment of Bool Lagoon Wellfield. Technical Report, South Australian Water Corporation, Adelaide.

[15] Gerber, R.E. and Howard, K. (2000) Recharge through a Regional Till Aquitard: Three-Dimensional Flow Model Water Balance Approach. Ground Water, 38, 410-422. http://dx.doi.org/10.1111/j.1745-6584.2000.tb00227.x

[16] Weiss, M. and Gvirtzman, H. (2007) Estimating Ground Water Recharge Using Flow Models of Perched Karstic Aquifers. Ground Water, 45, 761-773. http://dx.doi.org/10.1111/j.1745-6584.2007.00360.x

[17] Brown, K. (2000) A Groundwater Flow Model of the Tertiary Confined Sand Aquifer in South East South Australia and South West Victoria. Report Book 2000/00016, Department for Water Resources, Primary Industries and Resources, Adelaide.

[18] Harrington, N. and Lamontagne, S., Eds. (2013) Framework for a Regional Water Balance Model for the South Australian Limestone Coast Region. Technical Report Series No. 13/14, Goyder Institute for Water Research, Adelaide.

[19] Harrington, N.M., Chambers, K. and Lawson, J. (2007) Primary Production to Mitigate Water Quality Threats Project, Zone 1A Numerical Modelling Study: Conceptual Model Development. DWLBC Report 2008/12, Government of South Australia through Department of Water, Land and Biodiversity Conservation, Adelaide.

[20] Konikow, L.F. and Bredehoeft, J.D. (1992) Ground-Water Models Cannot Be Validated. Advances in Water Resources, 15, 75-83. http://dx.doi.org/10.1016/0309-1708(92)90033-X

[21] Beven, K. (1993) Prophecy, Reality and Uncertainty in Distributed Hydrological Modelling. Advances in Water Resources, 16, 41-51. http://dx.doi.org/10.1016/0309-1708(93)90028-E

[22] Oreskes, N., Shrader-Frechette, K. and Belitz, K. (1994) Verification and Confirmation of Numerical Models in Earth Sciences. Science, 263, 641-646. http://dx.doi.org/10.1126/science.263.5147.641

[23] Gupta, H., Sorooshian, S. and Yapo, P. (1999) Status of Automatic Calibration for Hydrologic Models: Comparison with Multilevel Expert Calibration. Journal of Hydrologic Engineering, 4, 135-143. http://dx.doi.org/10.1061/(ASCE)1084-0699(1999)4:2(135)

[24] Hendricks Franssen, H.J., Alcolea, A., Riva, M., Bakr, M., van der Wier, N., Stauffer, F. and Guadagnini, A. (2009) A Comparison of Seven Methods for the Inverse Modelling of Groundwater Flow. Application to the Characterization of Well Catchments. Advances in Water Resources, 32, 851-872. http://dx.doi.org/10.1016/j.advwatres.2009.02.011

[25] Boyle, D.P., Gupta, H. and Sorooshian, S. (2000) Towards Improved Calibration of Hydrologic Models: Combining the Strengths of Manual and Automatic Methods. Water Resources Research, 6, 3663-3674. http://dx.doi.org/10.1029/2000WR900207

[26] Saiers, J.E., Genereux, D.P. and Bolster, C.H. (2004) Influence of Calibration Methodology on Groundwater Flow Predictions. Ground Water, 42, 32-44. http://dx.doi.org/10.1111/j.1745-6584.2004.tb02448.x

[27] Eckhardt, K., Fohrer, N. and Frede, H. (2005) Automatic Model Calibration. Hydrological Processes, 19, $651-658$. http://dx.doi.org/10.1002/hyp.5613

[28] Moore, C. and Doherty, J. (2006) The Cost of Uniqueness in Groundwater Model Calibration. Advances in Water Resources, 29, 605-623. http://dx.doi.org/10.1016/j.advwatres.2005.07.003

[29] Yeh, T.J., Mao, D., Zha, Y., Wen, J., Wan, L., Hsu, K. and Lee, C. (2015) Uniqueness, Scale and Resolution Issues in Groundwater Model Parameter Identification. Water Science and Engineering, 8, 175-194. http://dx.doi.org/10.1016/j.wse.2015.08.002

[30] Holmes, J.W. and Colville, J.S. (1970) Grassland Hydrology in a Karstic Region of South Australia. Journal of Hydrology, 10, 38-58. http://dx.doi.org/10.1016/0022-1694(70)90053-3

[31] Holmes, J.W. and Colville, J.S. (1970) Forest Hydrology in a Karstic Region of Southern Australia. Journal of Hydrology, 10, 59-74. http://dx.doi.org/10.1016/0022-1694(70)90054-5

[32] Colville, J.S. and Holmes, J.W. (1972) Water Table Fluctuations under Forest and Pasture in a Karstic Region of Southern Australia. Journal of Hydrology, 17, 61-80. http://dx.doi.org/10.1016/0022-1694(72)90066-2 
[33] Allison, G.B. and Hughes, M.W. (1978) The Use of Environmental Chloride and Tritium to Estimate Total Recharge to an Unconfined Aquifer. Australian Journal of Soil Research, 16, 181-195. http://dx.doi.org/10.1071/SR9780181

[34] Leaney, F.W. and Herczeg, A.L. (1995) Regional Recharge to a Karst Aquifer Estimated from Chemical and Isotopic Composition of Diffuse and Localized Recharge, South Australia. Journal of Hydrology, 164, 363-387. http://dx.doi.org/10.1016/0022-1694(94)02488-W

[35] Department of Environment, Water and Natural Resources (2014) Prescribed Wells Areas of the South East Confined Aquifer: 2014 Groundwater Level and Salinity Status Report. Department of Environment, Water and Natural Resources, Adelaide.

[36] Love, A.J. (1991) Groundwater Flow Systems: Past and Present, Gambier Embayment, Otway Basin, South Australia. Master's Thesis, Flinders University of South Australia, Adelaide, 261.

[37] Harbough, A.W., Banta, E.R., Hill, M.C. and McDonald, M.G. (2000) MODFLOW-2000, The US Geological Survey Modular Ground-Water Model-User Guide to Modularization Concepts and the Ground-Water Flow Process. US Department of Interior, US Geological Survey, Open-File Report 00-92, Reston, VA.

[38] Chiang, W.-H. and Kinzelbach, W. (1998) Processing MODFLOW-A Simulation System for Modelling Groundwater Flow and Pollution. Hamburg, 342 p. www.pmwin.net

[39] Mustafa, S. and Lawson, J.S. (2002) Review of Tertiary Gambier Limestone Aquifer Properties, Lower South East, South Australia. Report DWLBC 2002/24, Department of Water, Land and Biodiversity Conservation, Adelaide.

[40] ROSETTA V1, USDA-ARS Salinity Laboratory, Riverside, US, 1999.

[41] Mustafa, S. and Lawson, J. (2012) South Australia-Victoria Border Zone Groundwater Investigation: Results of the Pumping Test Program. Technical Report DFW 2011/2, Department for Water, Adelaide.

[42] Benyon, R.G. and Doody, T.M. (2004) Water Use by Tree Plantations in South East South Australia. CSIRO Forestry and Forest Products Technical Report Number 148, CSIRO Mount Gambier SA, Australia.

[43] Hanson, R.T., Li, Z. and Faunt, C.C. (2004) Documentation of Santa Clara Valley Regional Groundwater Model, Santa Clara, California. Scientific Investigation Report 2004-5231, US Department of the Interior, US Geological Survey, Reston, VA.

[44] Leijnse, A., Pastoors, M.J.H. and Roelofsen, F.J. (2002) The Effect of Weighting the Observations on Parameter Estimates in Groundwater Modelling. In: Calibration and Reliability in Groundwater Modelling: A Few Steps Closer to Reality (Proceedings of ModelCARE 2002), IAH Publication No. 277, Czech Republic, 204-211.

[45] Carrera, J. and Neuman, S.P. (1986) Estimation of Aquifer Parameters under Transient and Steady State Conditions I: Maximum Likelihood Method Incorporating Prior Information. Water Resources Research, 22, 199-210. http://dx.doi.org/10.1029/WR022i002p00199

[46] Waterloo Hydrogeologic (2015) Visual MODFLOW 2011.1 User’s Manual. Waterloo Hydrogeologic, Waterloo, ON.

[47] Loucks, D.P., van Beek, E., Stedinger, J.R., Dijkman, J.P.M. and Villars, M.T. (2005) Water Resources Systems Planning and Management. An Introduction to Methods, Models and Applications. UNNESCO, Paris and Delft Hydraulics, The Netherlands.

[48] Brown, K., Harrington, G. and Lawson, J. (2006) Review of Groundwater Resource Condition and Management Principles for the Tertiary Limestone Aquifer in the South East of South Australia. DWLBC Report 2006/2, Department of Water, Land and Bio Diversity Conservation, Adelaide.

[49] Allison, G.B. and Hughes, M.W. (1972) Comparison of Recharge to Groundwater under Pasture and Forest Using Environ Mental Tritium. Journal of Hydrology, 17, 81-95. http://dx.doi.org/10.1016/0022-1694(72)90067-4

[50] Benyon, R., Thieveyanathan, T. and Doody, T.M. (2006) Impacts of Plantations on Groundwater in South-Eastern Australia. Australian Journal of Botany, 54, 181-192. http://dx.doi.org/10.1071/BT05046

[51] Benyon, R., Doody, T.M., Thieveyanathan, S. and Koul, V. (2008) Plantations Forest Water Use in Southwest Victoria. CSIRO Water for a Healthy Country Research Flagship, CSIRO, Canberra.

[52] Bevan, K.J. and Young, P. (2013) A Guide in Modelling Scenarios for Authors and Referees. Water Resources Research, 49, 5092-5098. http://dx.doi.org/10.1002/wrcr.20393

[53] Huntush, M.S. (1960) Modification of the Theory of Leaky Aquifers. Journal of Geophysical Research, 65, 3713-3726. http://dx.doi.org/10.1029/JZ065i011p03713

[54] Harrington, G. and Cook, P. (2011) Mechanical Loading and Unloading of Confined Aquifers: Implications for the Assessment of Long-Term Trends in Potentiometric Levels. Waterlines Report Series No. 51, National Water Commission, Canberra. 